ascertain what values of components should be used to reduce interference within the prescribed limits.

In a statement made by $\mathrm{Mr}$. C. C. Paterson, the chairman of the Committee, concerning the report, he points out that should the regulations be put into foree, the normal procedure would be very much as at present. There would not be an army of inspectors searching out for trouble. Action would only be taken by the Post Office on receipt of a complaint of interference, and these complaints would become fewer in number as new apparatus bearing the 'mark' came into use.

\title{
Industrial Development in South Africa
}

$\mathrm{T}$ HE Department of Commerce and Industry of the Government of the Union of South Africa has published a review of the material, scientific and educational progress made in connexion with the development of industry during the twenty-five years up to 1935*. Primarily, its purpose is to give an accurate picture of the conditions and prospects in what are described as the secondary industries, for agriculture and mining are otherwise dealt with and are only referred to in so far as they have a bearing on the other and less firmly established industries. The information it contains as to the conditions, facilities, costs, etc., in various districts and the progress of the numerous industries which have been established will also be found to supply a valuable scientific interpretation of the facts for the use of those who are or may become interested in the industrial future of the country.

In round numbers, the following figures give a picture of the expansion that has taken place in the twenty-five year period-employees have increased from 66,000 to 195,000 , horse-power from 140,000 to $1,400,000$, and total wages from 4 to 27 million pounds. The classes of industries dealt with and analysed statistically include fuel industries, iron and steel production, heavy chemicals and food production (sugar, wines and fisheries), together with other important developments which are taking place in connexion with the introduction of such manufactures as cement, pottery, clothing and textiles.

In these changes, the importance of research appears to be fully realized, and it is being fostered as an aid and guide in obtaining the best results. At Mount Edgcumbe, the sugar industry has, at a cost of $£ 13,000$, established an experimental station, which is run at an annual charge of about $£ 9,000$. On the agricultural side, its main function is the search for new canes of superior sugar content and of higher resistance to disease. There are also a chemical side, dealing with manufacturing methods and processes, and an engineering section to investigate mechanical problems.

The Union Government conducts research in connexion with the fisheries, investigating life-histories and the intensity of operations and engaging in technological research on canning, smoking and other processes. Marine biological work is carried on in the specially designed research ship Africana, which took over the duties in 1931, while shore investigations in this department are conducted at the Laboratory and Aquarium at St. James, near Cape Town.

In a country making rapid advances towards industrialism, and possessing rich stores of natural wealth, much special research is necessary in order

* Industrial Development in South Africa and Facilities for the Establishment of Factories. Published by the Department of Commerce and Industries. Edited by
Government Printer, 1936.) 18. to ascertain the best methods of making use of and adapting its resources to its own needs and that of export trade. Such work is being done on the coal supplies, the phosphates, the clays and other materials offering scope for increased usefulness. The use of gas, for example, might be greatly increased and developed.

The value of standardization has been recognized, and the editor takes the opportunity of impressing on his local readers its importance in eliminating ambiguous and misleading descriptions, in preparing dimensional standards and in specifying physical and chemical properties of materials, methods of testing, and safety codes. The South African Standards Institution, which is associated with the British Standards Institution, is conducted by a main committee representative of Government departments, technical societies and trade and industrial bodies, and there are five sectional committees dealing with mechanical, electrical and civil engineering, chemical and fuel matters respectively. In any work undertaken, the initiative lies with the interests concerned, and after tentative standards have been prepared they are submitted to the associated institutions, and those chosen are circulated for comment and recommendation. It is claimed that in this way the final standards approved should meet local conditions and requirements and then the industry or trade concerned may, if it desires, adopt them in its daily policy and practice.

It is to be noted also that a comprehensive scheme of training and technical education is now in being. The adoption, in 1922, of the Apprenticeship Act, marked the beginning of a new era in industrial legislation, and since then, 15,000 lads have completed their apprenticeships in accordance with its provisions and under the supervision of the committees of employers and employees which assist in its administration. The Act is operative in twelve groups of industries, and the general practice is a five-year training of young people after completing the primary and, in some cases, part of the secondary school course. They are then indentured to individual employers and are required to enrol for part-time courses at the technical colleges, a portion of their attendance there being timed to take place during ordinary working hours. For those resident in places far removed from centres where technical colleges exist, the Government has arranged for correspondence courses under the ægis of the Witwatersrand Technical College and, where students show satisfactory diligence, employers are responsible for the class or correspondence fees. It will thus be seen that South Africa is making every endeavour to provide for the needs of her technical students in the most practical way, and it may be premised that these preparations will react most favourably upon future industrial developments. 